\title{
Enduring the Loneliness inside the Catholic Diocesan College Seminary
}

\author{
Genesis B. Naparan', Seminarian Clive Jarry S. Kingco ${ }^{2}$, Seminarian Arnel G. \\ Bolivar $^{3}$, Seminarian Ralph Kenneth S. Salinas ${ }^{4}$ \\ ${ }^{1}$ Saint Columban College, Pagadian City, Philippines \\ ${ }^{2}$ Saint Mary School of Theology, Ozamis City, Philippines \\ ${ }^{3,4}$ Holy Infant Seminary, Pagadian City, Philippines \\ sccresearchoffice@sccpag.com, clivejarrykingco@yahoo.com.ph, arnelbolivar098@gmail.com, \\ ralphkennethsalinas@gmail.com
}

\section{Abstract}

Seminarians inside the Seminary experienced many difficulties. One of them is the experience of loneliness. The present research examined the ways of enduring the loneliness inside the Seminary. The purpose of this study is to help improve the commitment in the priesthood. The researchers used a qualitative transcendental phenomenological approach in exploring the experiences of nine college seminarians. Phenomenological is an approach to qualitative research that describes the meaning of several individuals' lived experiences, which in this research talks about the seminarians' loneliness inside the Seminary. The forms of loneliness experienced by the seminarians are classified into three themes: 1) Seminary-Related Loneliness; 2) Living away from the family, and 3) Being alone. The seminarians deal with their experienced loneliness through Social Interaction, Prayer, and making the Self Busy. The results reveal that loneliness inside, although inevitable, can be prevented through prevention measures. Future researchers may conduct a further study on how to improve the seminarians' lives inside the Seminary to help the seminarians be more committed to the priesthood.
Keywords loneliness seminary, priesthood

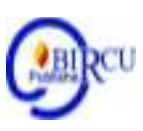

\section{Introduction}

A seminary is a place of contemplation and structured living. Those who answer the call for Ministerial Priest undergo a large formation to be formed in interior silence. Pope Benedict XVI emphasizes that seminarians must cultivate an intimate friendship with Jesus in meditation and prayer. This idea implies that in the life of a seminarian, there should be a process of formation. These series of formation formed the seminarians in different aspects of human formation. One of these aspects is Spiritual Formation that emphasizes seminary silence (Keating, 2012). Silence and contemplation have a purpose. The seminary gives a mandatory silence within the seminary to help seminarians attain this union with God. Contemplative silence can lead then to the spiritual growth of the seminarians (Leong, 2019). Thus, most seminaries forbid the use of gadgets as an escape route that could squander the seminary's external silence (Keating, 2012). Consequently, some seminarians might feel a monotonous or boring life inside the seminary.

Aside from being partnered with contemplation, silence is a good practice for selfdirected learning (Dao, 2020). Being silent in the seminary does not just pertain to moments of prayer and reflection. The seminarians need to excel as well in their academics. They have courses taken that needed to be passed. 
Genesis B. Naparan, Seminarian Clive Jarry S. Kingco, Seminarian Arnel G. Bolivar, Seminarian Ralph Kenneth S. Salinas: Enduring the Loneliness inside the Catholic Diocesan College Seminary https://siasatjournal.com/index.php/siasat

Many things influence a seminarian to leave the seminary. Some of these are the human relationship pitfalls such as busyness \& Loneliness (Wagener, 2004). Loneliness's experience is an unfavorable factor that causes seminarians to leave the seminary formation (Sunardi, 2014). For some seminarians, seminary life becomes stressful as they highlight that they are not as free as other college students (Win, \& Ho, 2016). Thus, many seminarians opt to end their seminary formation and continue to study as regular students.

There is a need to address the seminarians' issues in the formation process since if they remain unresolved, they can still recur when they become priests. One example of future problems is priests' sexual misconduct due to loneliness, unresolved issues in the past, failure to maintain boundaries, and lack of balance (Espina, 2020). Therefore, this research explored a common problem in living inside the seminary, which is loneliness. Most of the seminarians are living far from their families. Many of them opted to quit their priestly formation and started to live in everyday life. This phenomenon triggered the researchers to explore the seminarians' experiences in dealing with loneliness inside the seminary.

\section{Review of Literatures}

In coping with the seminarians' experiences of loneliness while living in the seminary, A General Attribution Theory for the Psychology of Religion by Spilka, Shaver, \& Kirkpatrick (1985) can help. The theory centers on individuals' three needs, namely: a sense of meaning, control over the outcomes, and self -esteem. To have a fruitful stay in the seminary, the seminarians need to find meaning in it. Seminary can be worth living also when seminarians have control over the circumstances they encounter inside the seminary. Lastly, their self-esteem needs to be nurtured, as this will lead to successfully coping with their experienced loneliness.

\section{Research Objectives}

This research aims to know how the seminarians endure loneliness in one of the Diocesan Catholic Seminaries in Southern Mindanao, Philippines. The research then explored the different forms of loneliness that these seminarians experienced while staying in the seminary. The research then solicited the seminarians' ways of dealing with their experienced loneliness to continue their next stages of formation.

\section{IIII. Research Methods}

\subsection{Research Design}

The researchers' purpose of this research is to look at how seminarians endure the seminary's loneliness. The research involved the personal experiences of the seminarians as the core of this research. A qualitative hermeneutical phenomenological approach was used in this research. A phenomenology is an approach to qualitative research that describes the meaning of a lived experience of a phenomenon for several individuals (Husserl, 2012), which, in this case, is the experience of loneliness inside the seminary. There are two main types of phenomenology: Hermeneutical and transcendental. The latter is applied in this study. The transcendental phenomenology approach by Moustakas (1994) ate the essence of the lived experience, as opposed to hermeneutical phenomenology, which more strongly relies on the researcher's interpretations of what the lived-experience means. The researchers bracketed their biases about their ideas in living inside the seminary to portray the essence of the research participants' experiences. 


\subsection{Research Environment}

This research was conducted only in the Holy Infant Seminary. It is the heart of the Diocese of Pagadian. A seminary is a place or school for those male students or seminarians who wanted to become a priest. It is managed by the priest led by a Seminary Rector and a Dean of Studies, Dean of Seminarians, Seminary Bursar, and Spiritual Director. The Seminary is in Ballesteros Village, Balangasan District, Pagadian City, Philippines. The Formation Program or Curriculum of the Holy Infant Seminary lasts for five years in total, one year of Propaedeutic Stage, and four years of Discipleship year. One of the primary formations or curricula inside the seminary is to live in silence or solitude to prepare the seminarians for more contemplative life. For this purpose, the seminary became a quiet place, causing some seminarians to experience loneliness.

\subsection{Research Participants}

The participants of the research are the nine seminarians of the Holy Infant Seminary. These young seminarians have stayed in the seminary for two or more years. They belong to the Discipleship stage of formation. Besides the seminary responsibilities, these seminarians have to satisfy the demand of their Bachelor of Arts in Philosophy course in college. Their ages range from eighteen to twenty-four years old. All of them have left their families for the first time as they responded to their vocation. The research participants were chosen purposively. Only those who experienced loneliness and chose to stay in the seminary formation were included in the study.

\subsection{Data Analysis}

The researchers rely on the interview script that was gathered from the interview of the seminarians. In analyzing the data, the researchers used the phenomenological analysis of Hycner (1985). The researchers emphasized the suspension of their biases to explore the essence of the participants' experiences. They then delineated the codes and formed general meanings of the experiences. They linked the arrived meanings to the research objectives that they explored in this study. The themes then emerged at the end part of the analysis. As the themes emerged, the researchers reported the findings to the research participants.

\subsection{Ethical Consideration}

This research involved human participants, namely, seminarians of the Holy Infant Seminary. Concerning the participants, the researchers followed the ethical guidelines in doing research. They asked permission from the institution of the participants. The researchers also paid attention to several important issues of sending consent, ensuring voluntary participation, and observing confidentiality in research.

\section{Results and Discussion}

\subsection{Results}

This study's results are presented according to the forms of loneliness and the ways of dealing with these forms of loneliness while staying in the seminary.

\section{a. Forms of Loneliness}

Based on the collected data, the researchers found three key themes of what form of loneliness experienced by the seminarians of Holy Infant Seminary. Figure 1 presents the themes in the form of loneliness experienced by the research participants. 


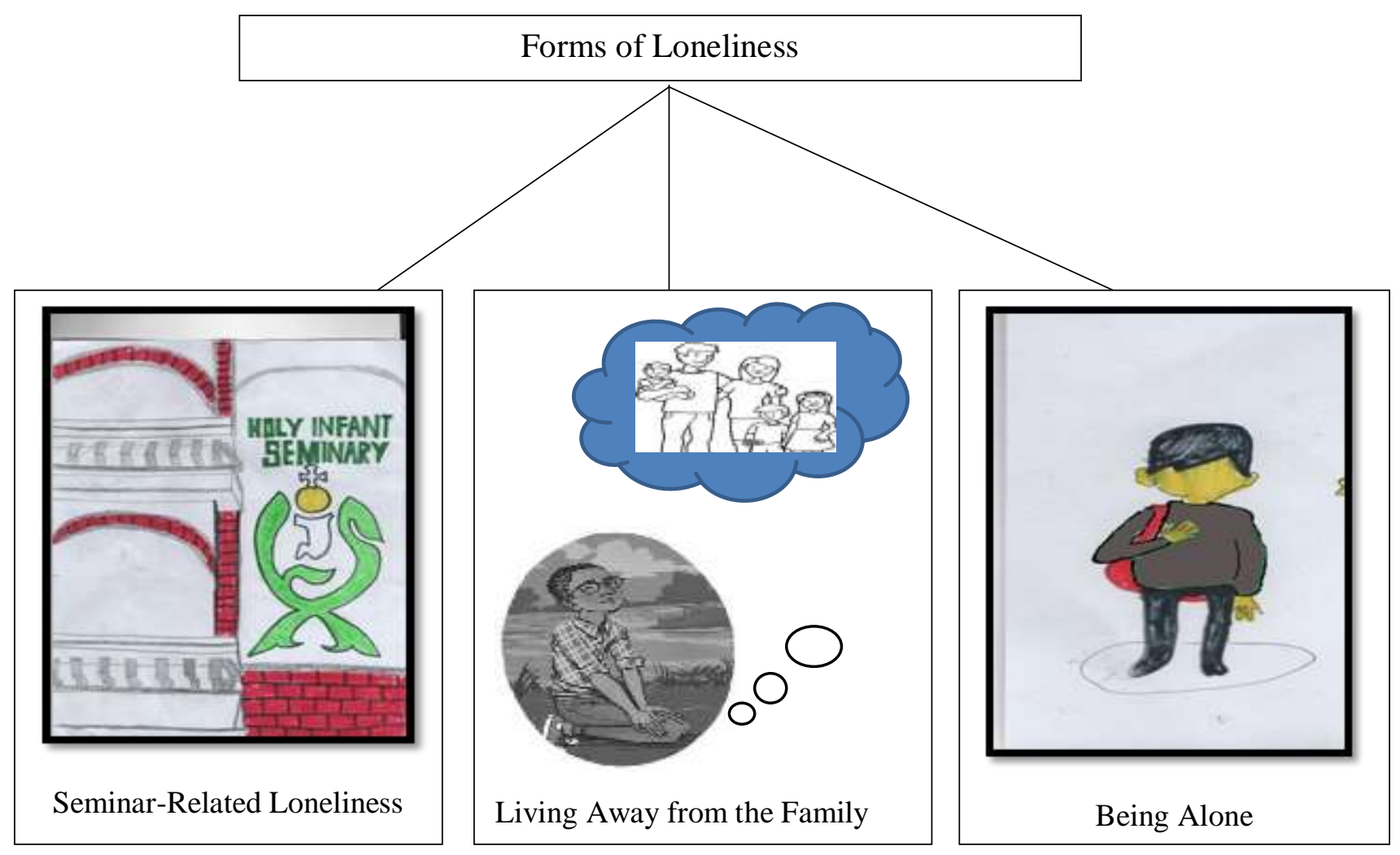

Figure 1. Form of Loneliness inside the Seminary experienced by the seminarians

\section{b. Ways of Enduring Loneliness inside the Seminar}

Loneliness is more responsible for the decision process of regency. When loneliness is absent, resignation from the priesthood or dropout from seminary is unlikely (Sunardi, 2014). Figure 2 presents the themes on how the seminarian endure the loneliness inside the seminary, namely, social interaction, praying, and keeping the self-busy.

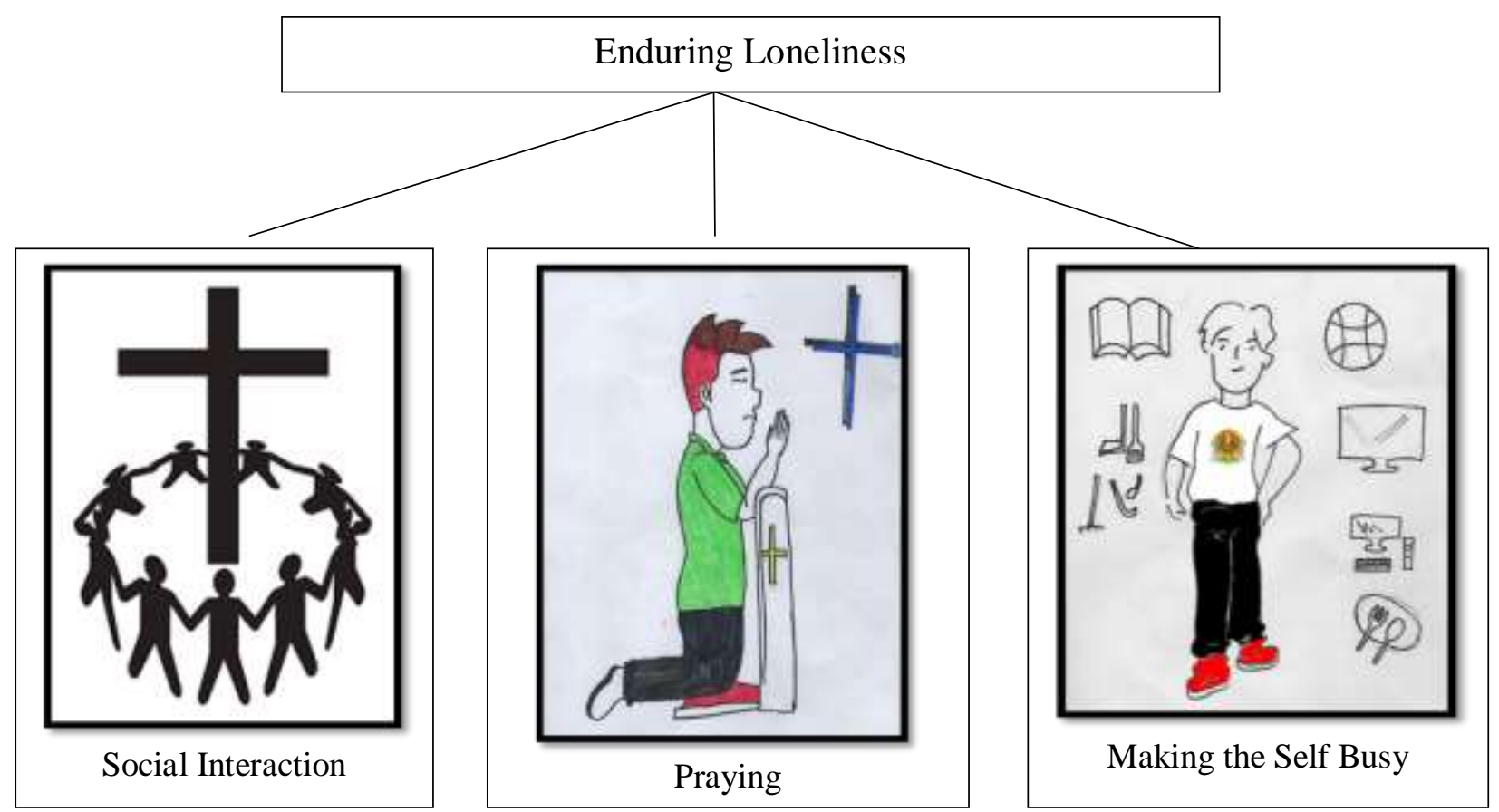

Figure 2. Ways in Enduring Loneliness inside the Seminary 


\subsection{Discuission}

Upon staying inside the seminary, the research participants experienced different forms of loneliness. They are seminary-Related loneliness, living away from the family, and being alone. The seminary-related loneliness included subthemes such as silence inside the seminary, bullying, misunderstandings with the community, and difficulty coping with the seminary schedule and academic requirements. The seminary formation program consists of many aspects (Vatican II: Optatam Totius). One of these is the Human Formation, in which the seminarians should learn to transform "the experience of loneliness into holy Solitude (PPF 79). Seminarians then experienced loneliness because of the silence inside the seminary. It is a kind of loneliness that new seminarians usually felt because of the new environment of the seminary. According to Seminarian A:

I felt the loneliness inside the seminary because of the silence, which is new to me.

It has a significant impact on me because I am used to the noise.

The main task of seminary formation is to educate seminarians in interior silence (Keating, 2012). A seminary horarium for mandatory silence is essential. However, sometimes, those who experience silence usually encountered it as suffering. According to the experiment conducted at a Benedictine abbey in 2010 in England, when several laypeople spent many days in silent retreat, they first encountered silence as pain, and silence itself was excruciating.

Another Seminary-Related loneliness experienced by the seminarian is through bullying. Bullying is a common problem in any institution. In the seminary, bullying can affect a seminarian's mental health and results in loneliness. According to seminarian A:

The community bullied me through name-calling; that is why I am lonely at that time. I felt the pain; that is why I chose to stay away from the community. Seminarian A

Bullying victimization and perpetration, and prevalent adverse social events in many adolescents' lives may degrade the seminarians' meaningful life (O'Donnell, 2015). Seminarians who experience loneliness most likely keep away from the community, affecting their willingness to continue seminary formation.

Other Seminary-Related Loneliness experienced by the seminarians is the misunderstanding in the community. Seminary is a diverse community. Every seminarian has different attitudes and personality, and sometimes there some do not get each other's kind of thinking. This results in the seminarians are different from each other. According to the following Seminarians:

Sometimes they do whatever they wanted, and I cannot entirely agree. It makes me the enemy of the community and aloof to the community. Seminarian D

I felt lonely when I have problems, and no one can help me. They say that the community will help, but I did not feel that. - Seminarian C.

In countless seminaries, the brothers do not live together in unity (Fitzgibbons, 1989). Some seminarians are lonely because they lack trust in their brother seminarians. Other fears that close interpersonal relationships result in more stress and pain than in comfort and happiness. This kind of loneliness could affect the seminarians' response to their community life, which is one of the main aspects of the seminary. A seminarian who cannot deal with the community has a less surviving rate in the seminary. 
Lastly, seminarians experienced Seminary-Related loneliness because of the difficulty of seminary schedule and requirements. The seminary integrates the responsibility of the seminarians in the school and the seminary. Some seminarians experienced difficulties in multitasking, and it results in being busy, which leads to loneliness. Seminarian C stated:

I have difficulties following the seminary schedules because it is very hectic...

(And) I have many requirements, so I can say the schedule is hectic.

Loneliness in seminarians includes an excessive sense of responsibility for seminary activities. This loneliness results in preoccupations with worries and too little time for ongoing friendships (Fitzgibbons, 1989). The seminary forms seminarian to be responsible enough to comply with seminary works. However, some seminarians felt difficulties because of the responsibilities they cannot observe.

Living away from the Family. Another form of loneliness in living inside the seminary is the loneliness of being far from the family members. The seminary program requires the seminarian to live inside the seminary. It is inevitable for the seminarians to leave their families. It causes the seminarians to experience the loneliness that is common to many college students. According to the participants:

I miss my family back home, and I long for their presence. - Seminarian B

My family is my inspiration, but there are times that I missed them, and that makes me lonely. It is common to be separated from the family and miss them. They are their reason why I feel lonely in the seminary because they were not there when I needed their help. - Seminarian D

I am lonely because I missed my family and loved ones - Seminarian E I missed my family because in the seminary we are far from them. There are no longer parents that take care of me, and I missed their love. In the seminary, although they said that formators are the second parents of the seminarians, but they cannot become father and mother to us. That is why, I am longing for the love of my real family though we have a new family here in the seminary, we have our own unique family, which is the source of our vocation. - Seminarian F

I missed my family because this kind of life that I am facing is not an ordinary life. It is new to me. I missed my family even though I have many companions. I have many friends because I am good in socializing, but I cannot deny that I missed my family. - Seminarian G

Many Seminarians fall to loneliness because there is a failure to experience a family life of love flowed between a mother and a father (Fitzgibbons, 1989). This particular emotional pain may predispose a seminarian to feel very sad in the seminary in which seminarians do not get along well. It reminds the seminarians of the distance and unhappiness between his parents.

Living Alone. The seminary program allows the seminarians to discern their priestly vocation through mediation and reflection. The seminary also prepares the seminarians for their future ministry of celibacy, which is being alone. Because of this, the seminarians inevitably experienced loneliness inside the seminary. According to the seminarians:

I was always alone because many of my batchmates already went out from the seminary. Sometimes, I stayed in my room, and I refrained from talking to others. It 
looks like I imprisoned myself in my chamber, and I feel aloof from the community. - Seminarian A

I was alone in the seminary because I do not have friends and people to talk to.

Sometimes, I felt like when I have problems, they cannot relate to my problems. Seminarian B

The seminary is very lonely that sometimes I thought of going out from it. Seminarian E

Loneliness primarily refers to the lack or absence of companionship and intimacy. Loneliness is a painful state result from unfulfilled basic needs for companionship and intimacy (Sunardi 2014). Some seminarians have difficulty living the life of a priest, mainly because of being alone. In the worse cases, some seminarians sometimes leave the seminary after experiencing loneliness because they believe that their sadness is caused solely by their priestly vocation. They will never be happy living in the seminary.

\section{Ways of Dealing the Loneliness in Living inside the Seminary}

Based on the research participants' experienced loneliness, they also shared their ways of dealing with loneliness. The three essential practices that helped them persist with their chosen vocation. As they experienced loneliness, they tried to combat it with social interaction, prayer, and keeping themselves busy.

Social Interaction. The number one reason for loneliness is the lack or absence of companionship. However, some seminarians make fair use of their social skills to endure this loneliness. They could easily endure their loneliness by chatting, fitting in, knowing, and seeking advice from other seminarians. Some seminarians seek encouragements from their family who supports them. According to the seminarians:

I can endure loneliness because of my brother seminarians. I interact with them, knowing them, and experiencing their lives as well - Seminarian B

I cope with loneliness through fitting-in to the community and talking with my brother seminarians. - Seminarian E

There are times that I go to my friends (he stated the name of his friends). They are my best friends and real friends. They help how to overcome loneliness, and they taught me how to smile even though there are some problems that I am facing. Seminarian G

I can endure my loneliness to my Family by merely communicating to my brother seminarians and telling them my problems, strength, and doings inside the Seminary. - Seminarian B

Studies have suggested the critical role of encouragement and social support in the priesthood. Encouragement might be different from social support, but both represent the relationship role. Those seminarians who had reported being encouraged, having close friends in the seminary, and feeling satisfied with the community's life in the seminary were more likely to remain in the Seminary (Sunardi, 2014). For the seminarians, encouragement functions as a support for their priestly vocation, and Parental care will positively correlate with an affective commitment to the seminary. Social support in the 
seminary can also be done by mentoring and ministerial formation. When the seminarians embrace the sense of community, they will become academically engaged (Chukwuorji, Ifeagwazi, Nwonyi, \& Ujoatuonu, 2018).

Praying. The Seminary formed seminarians to become more prayerful. At the end of the College Seminary Formation, the seminarian can integrate the value of prayer in their lives. Through prayers, most of the seminarians endure the challenges inside the SeminarySeminary, particularly loneliness. According to the seminarians:

In times of bullying, I went to the Chapel and meditated because God will help me in my loneliness and pains. - Seminarian A

I have only one way to endure loneliness that is to believe and not to believe the people who surround you. I believe the man who removes that loneliness, and that is God. Just believe in Him, and just to pray, that is what I am always doing. Seminarian D

Because I missed my family, I prayed to God that He will protect them. Seminarian E

Whoever wants to be a friend of Jesus and become his authentic disciple-be it seminarian, priest, religious or layperson - must cultivate an intimate friendship with him in meditation and prayer (Pope Benedict, 2006). The Seminary allows the seminarian to experience Jesus in their prayer because God is the one who chooses the unworthy to be His priest. It requires the divine intervention from God to every trial and challenge that comes to seminarians' lives to remind that God gives the grace of vocation.

Keeping the Self Busy. The seminary program allows the seminarians to be creative in following seminary structure. Some seminarians found ways and techniques to overcome the loneliness inside the Seminary. According to the Seminarians:

There are many ways of enduring loneliness. When I was alone in the room, I look for enjoyment such us reading the Bible and reading materials so that I won't feel the loneliness in me. - Seminarian A

To endure loneliness inside the Seminary, first, I make myself busy. Being busy makes the time unnoticeable. Doing nothing makes the time slow. Working removes one's loneliness as the years will pass away. The Seminary is very lovely because time is swift because of the structure that makes a seminarian occupied. Although in the silence of the heart, there is still loneliness, but it can be healed and buried because of the work every day. - Seminarian F

Sometimes I make my happiness like cleaning the room, and sometimes I reminisce about the memories that make me happy. - Seminarian $\mathrm{H}$

Boredom can be experienced if there are no challengers in life. To endure boredom, it is an excellent way to keep oneself busy by doing something, whether it is productive or not. Having a hobby in the Seminary helps a seminarian to endure the loneliness. The Seminary also recognizes the seminarians' individual talents to develop their capabilities like music, sports, and literature. Particularly, in the research environment of this study, some of this seminary programs are the guilds: Vox Dei (Voice of God), for those who love music and singing; Journey Publication, for those who want to write their articles; BaHanDi (Balaang Handuman sa Dios), for those who have talents in dancing; Arco, for 
those who love arts; and Formandi (Seminarian), the name of the varsity that participates on basketball leagues.

This research presented three ways of dealing with loneliness inside the seminary: social interaction, praying, and keeping the self-busy. Seminarians came to the seminary, having different family backgrounds and belief systems. Most of them are coming from religious families. To successfully finish the formation process, seminarians need to have support from their family, bishop, formators, friends, and co-seminarians (McCormack, 2020). Seminarians need to overcome challenges in the seminary, including their experienced loneliness and undergo transformations of healing the woundedness in the past, coping with the academic requirements, and strengthening their beliefs in God.

Even if the seminarians became priests, they are still not free from challenges in life. Many priests suffer from distress because of loneliness, hurts, compassion fatigue, loss of vitality, low-quality accommodation, financial worries, and even family worries (Sweeney, 2016). In addressing these forms of distress, these priests sought conversation with experts as well as their companions. So, the seminarians must learn how to deal with their burdens while undergoing seminary formation so that when they become priests, they already know what to do during troubling times.

\section{Conclusion}

Based on the gathered data from the seminarians' interview, the prominent cause of loneliness is the Seminary-Related loneliness. There are some seminarian experiences the difficulties in living the seminary structure. There are also misunderstanding and mistreatment that occurs between some seminarians. Another cause of loneliness is that the seminarians must depart from their families to live in the seminary. This problem is common to every child who leaves the presence of their parents for the first time. Lastly, another of loneliness is the failure to live the seminary's community life that causes on being alone. There are some difficulties in living in the seminary, especially if a seminarian lacks social flexibility, which is vital to living in the seminary's community life.

Loneliness is not a problem that cannot be solved. The seminarians learned to endure loneliness through the seminary and other seminarians. The community life enables the seminarians to endure their loneliness from their families. Some seminarians recognize the importance of prayer in living inside the seminary. Lastly, some seminarians learned to use their time pleasurably. This technique enables the seminarians to put themselves to the things that make them occupy and forget about time until they reach their goal, to be a priest.

\section{References}

Chukwuorji, J.B.C., Ifeagwazi, C. M., Nwonyi, S. K., \& Ujoatuonu, I. V. N. (2018). Sense of Community and Academic Engagement in the Seminary. Journal of Research on Christian Education, 27 (1), 20-38. DOI: 10.1080/10656219.2018.1447412.

Dao, B. (2020). Exploring How Silence Communicates. English Language Teaching Educational Journal (ELTEJ), 3(1), 1-13. Retrieved from https://bit.ly/2TcQQ1V.

Espina, M. L. A. C. (2020). Clergy sexual misconduct: through the lens of the lost shepherds. Asian Horizons, 14(2), 493-506. Retrieved from http://dvkjournals.in/index.php/ah/article/view/2915.

Fitzgibbons, R. P. (1989). Identifying, resolving loneliness in priestly life. The Priest, (September 1989), 10-17. 
Husserl, E. (2012). Ideas: General introduction to pure phenomenology. Routledge.

Hycner, R. H. (1985). Some guidelines for the phenomenological analysis of interview data. Human studies, 8(3), 279-303. Retrieved from https://bit.ly/34gRchw.

John Paul II (1992). Pastores dabo vobis. Acta Apostolicae Sedis, 84, 657-864

Keating, J. (2012). Seminary formation and interior silence. Nova et vetera, 10(2), 307319. Retrieved from https://bit.ly/2HkjNJT.

Leong, K. H. (2019). Word to Silence: Facilitating Contemplative Silence among Mandarin Speakers in the Malaysia Baptist Theological Seminary. Retrieved from https://bit.ly/3jiZzNS.

McCormack, E. J. (2020). A Guide to Formation Advising for Seminary Faculty: Accompaniment, Participation, and Evaluation. Catholic University of America Press.

Moustakas, C. (1994). Phenomenological research methods. Sage publications.

O'Donnell, M. B. (2015). The impact of bullying and act variables on meaning in life for adolescents. Retrieved from http://hdl.handle.net/10217/170309.

Schuth, K. (2016). Seminary formation: Recent history-current circumstances-new directions. Liturgical Press.

Spilka, B., Shaver, P., \& Kirkpatrick, L. (1985). A General Attribution Theory for the Psychology of Religion. Journal for the Scientific Study of Religion, 24(1), 1-20. doi: $10.2307 / 1386272$

Sunardi, Y. (2014). Predictive factors for commitment to the priestly vocation: A study of priests and seminarians.

Sweeney, P. (2016). Supporting Priests. The Furrow, 67(10), 535-550. Retrieved from http://www.jstor.org/stable/44738439.

VandenBos, G. (2006). The APA Dictionary of Psychology. Washington, DC: American Psychological Association.

Wagener, L. (2004). Surviving Seminary relationally. Fuller Theological Seminary, "The Semi (10-18-2004)" (2004). The SEMI (2001-2010). 127. Retrieved from https://digitalcommons.fuller.edu/fts-semi-6/127. 